DOI: https://doi.org/10.34069/AI/2021.47.11.17

How to Cite:

Yunin, O., Komisarov, S., Shebanits , D., Naumenko, S., \& Steblianko, A. (2021). Discrimination in sports as a gross violation of human rights in Ukraine. Amazonia Investiga, 10(47), 173-179. https://doi.org/10.34069/AI/2021.47.11.17

\title{
Discrimination in sports as a gross violation of human rights in Ukraine
}

\section{Дискримінація в спорті як грубе порушення прав людини в Україні}

Received: October 28, 2021

\section{Abstract}

The urgency of the problem described in the article is the existence of an ineffective observance mechanism of athletes' and fans' rights in connection with the manifestations of discrimination in sports. Therefore, the purpose of the article is to find ways to improve Ukrainian legislation in terms of protection of human rights from any manifestations of discrimination. To achieve this goal, the system-structural method and the formal-legal method, the method of analysis, the formal-logical method were used. The Ukrainian legislation in the researched field is analyzed. The experience of other countries in combating discrimination in sports has been studied. It is proposed to create an institute of sports ombudsman in Ukraine and stressed the need not to improve the criminal legislation in terms of clarifying the provisions of Article 161 of the Criminal Code of Ukraine. The expediency of establishing administrative liability for non-
Accepted: November 29, 2021

Written by:

Oleksandr Yunin ${ }^{73}$

https://orcid.org/0000-0003-4846-2573

Web of Science researcher code: AAP-5453-2021

Sergii Komisarov ${ }^{74}$

https://orcid.org/0000-0002-3101-964X

Web of Science researcher code: AAY-1925-2021

Diana Shebanits ${ }^{75}$

https://orcid.org/0000-0002-8897-9721

Web of Science researcher code: AAX-6159-2021

Sergii Naumenko ${ }^{76}$

https://orcid.org/0000-0002-4718-4957

Web of Science researcher code: ABC-6465-2021

Alina Steblianko ${ }^{77}$

https://orcid.org/0000-0002-5080-0490

Web of Science researcher code: AAC-8945-2021

\footnotetext{
${ }^{73}$ Doctor of Legal Sciences, Professor, Professor of the Department of Civil Law and Process of Dnipropetrovsk State University of Internal Affairs, Ukraine.

${ }^{74}$ Doctor of Juridical Sciences, Associate Professor, Vice-Rector, Dnipropetrovsk State University of Internal Affairs, Ukraine.

75 Candidate of History science, Associate professor of Law and Public administration department, Mariupol State University, Ukraine.

${ }^{76}$ Candidate of Juridical Sciences, Sumy branch of National Scientific Center «Hon. Prof. M. S. Bokarius Forensic Science Institute» Ukraine.

${ }^{77} \mathrm{PhD}$ in law, Assistant of the Department of Fundamental Jurisprudence and Constitutional Law, Sumy State University, Ukraine.
} 
compliance with anti-discrimination legislation, amending the Code of Ukraine on Administrative Offenses, which, in turn, will facilitate more prompt prosecution for human rights violations in sports. The practical value of the obtained results is that it can be taken as a basis for finding a mechanism to improve the fight against discrimination in sports.

Key words: prohibition regulations, universal values, rights of athletes, racial discrimination, sports ombudsman.

\section{Introduction}

The role of sport in society has become increasingly important over the years, either for the individual and public health (Malm, Jakobsson, \& Isaksson, 2019). Moreover, analysis of the provisions of the scientific doctrine, international treaties and national legislation shows (Reznik, Muzychuk, Andriichenko, Yakushchenko, \& Korzh, 2020) that sport is an important means of promoting and strengthening universal respect for human rights, used to combat all forms of discrimination, including racism and xenophobia (United Nations, 2015), therefore $64 \%$ of EU citizens regard sport as a means of combating discrimination (Katsarova, 2021).

At the same time, sport, despite its significant positive impact, can provoke negative phenomena, which can result human rights violations. In particular, we are talking about discrimination. According to research of the University of Central Florida's Institute for Diversity and Ethics in Sport (TIDES), acts of racism in sports in the U.S. sharply decreased from 52 acts in 2018 to just 25 in 2019. However, over the globe, there were 131 occurrences in 2019 compared to 137 in 2018. In 2019, according to TIDES, a large amount of the international documented racist acts have occurred during professional soccer games. From 131 racist acts in sports in 2019, 81 of them $(62 \%)$ were related to soccer, the most popular and most played sport in the world. Most of the discrimination was targeted toward African, наголошено не необхідності удосконалення кримінального законодавства у частині уточнення диспозиції статті 161 Кримінального кодексу України. Вказано на доцільність встановлення адміністративної відповідальності за недодержання антидискримінаційного законодавства, внісши відповідні зміни до Кодексу України про адміністративні правопорушення, що, у свою чергу, сприятиме більш оперативному притягненню до відповідальності за порушення прав людини у сфері спорту. Практична цінність отриманих результатів полягає в тому, що останні можуть бути взяті за основу при пошуку механізму удосконалення протидії та боротьби 3 дискримінацією у сфері спорту.

Ключові слова: заборонні постанови, загальнолюдські цінності, права спортсменів, расова дискримінація, спортивний омбудсмен.

Muslim and foreign-born players on opposing teams within these countries' top leagues such as the Serie A in Italy and the English Premier League in England (Lapchick, 2020). Speaking of Ukraine, in order to obtain official information on human rights violations based on gender, race, color, participation in sports, they convincingly point to the current facts of discrimination in the Ukrainian sponsor.

As we can see, the problem of discrimination in parties exists both in Ukraine and around the world, even though the rules on nondiscrimination are enshrined in the national legislation of each country, as well as at the international level. In addition, discrimination is observed against both fans and athletes. Therefore, the study of issues against human rights in sport is relevant, but discrimination is a gross violation of human rights as a universal value.

\section{Theoretical framework}

The theoretical basis of the study of discrimination in sports, which is a threat to human rights violations, are the scientific works of both domestic and foreign scientists. D. Kilvington and J. Price point out that, despite education and awareness increase campaigns, discrimination continues to be a deep-rooted problem in sport (Kilvington, \& Price, 2018). In turn, M. Zenquis and M. Mwaniki indicate that there is a desperate need to rethink the place of 


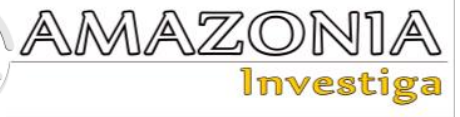

sport in global society, which, necessarily, includes deconstructing of White supremacy and our deterministic views on race, gender, and ethnicity (Zenquis, Mwaniki, 2019).

J. Phillips says that, two patterns of discrimination have been identified: (1) black players exclusion from central, leadership positions and (2) black players marginal ability exclusion from the opportunity to play (Phillips, 1997).

At the same time, O. Shevchenko notes the need of distinguishion between differentiation and discrimination in sport. In addition, the information that they appear differs from the following main characteristics: (a) the subject of differentiation acts as a rule-making body or the social partners who have the right to adopt normal legal or collective acts of trust; (b) the differentiation may be both "positive" and "negative"; (c) the grounds of differentiation may be combined or subjective designations (Shevchenko, 2010).

Scientists say that sport organisations continue to place a low priority on addressing the exclusion and discrimination experienced by LGBTQ+ people (lesbian, gay, bisexual, trans, questioning/queer, and sexual/gender diverse). It was previously thought that this was due to the lack of quantitative evidence of the problem; however, a huge amount of quantitative research has been conducted over the last decade, including two international studies that provide strong evidence that discriminatory behavior remains prevalent in sport and is detrimental to this population (Denison, Bevan \& Jeanes, 2021).

P. Oliver, J. Lusted emphasize the problem of unwillingness and ignorance of filing a complaint in the event of any form of discrimination. This reluctance is due to a general lack of understanding of the complaint and the procedure of its processing (Oliver, \& Lusted, 2015).

S. Teetzel and C. Weaving draws attention to the absence of inclusive policies for trans athletes has resulted discrimination, exclusion, and harassment. This is especially evident with the case of trans athletes in the 21 st century. Social inclusion in sport means the actual existence of equal opportunities to access (Teetzel, S., Weaving, C. (2017).). Good practices are the promotion of widespread sports, and the presence of people that tend to be excluded from the development of leadership and technical activities in society. This means that no discrimination exists in the access to these positions based on racial, ethnic, religious, disability, gender, sexual orientation, social class grounds, or others (Marivoet, 2014).

According to S. Patel (2021), recent years have witnessed increasing attention to the promotion of athletes' human rights, and this has given the rise to determining how to guarantee those rights in the context of sport. As athletes are increasingly finding their own voice and asserting their rights, the question how to balance the interests of sport with the protection of human rights of the athlete arises (Patel, 2021).

\section{Methodology}

Both general and special methods of cognition were used in the research process. Thus, thanks to the system-structural method, in a phase Theoretical framework the latest publications on the issue of discrimination in sports, which is a threat of human rights violations, were considered, and the results of the research were systematically presented. The formal-legal method allowed the analysis of the legal bases of human rights violations in connection with discrimination in sports in a phase Ukraine's experience in combating and combating discrimination in sport. The method of analysis, which we used in phases Legal basis for human rights violations related to discrimination in sport and International experience in combating and combating discrimination in sport made it possible to determine Ukrainian legislation and the positive foreign experience in combating and combating discrimination in sports. For its part, the formal-logical method, used in phase Ukraine's experience in combating and combating discrimination in sport made it possible to formulate proposals for improving the mechanism for combating and combating discrimination in sports. The article contains 26 references, of which 21 are references to scientific sources (Web of Scince and Publons databases), and 5 are references to legal sources.

\section{Results and discussion}

Legal basis for human rights violations related to discrimination in sport

Existing international standards reaffirm the value of human rights, as well as the importance and need to ensure that their rights in the field of sport are protected from discrimination. Even though at the international level there is a fairly extensive legal framework for the prevention of 
discrimination in sport, some forms of discrimination are still widespread. Thus, the principle of non-discrimination is enshrined in Art. 7 of the Universal Declaration of Human Rights, which states that all people are equal before the law and have the right to equal protection against any discrimination and against any incitement to such discrimination (United Nations, 1948).

The International Convention against Apartheid in Sport, which enshrines the legal definition of apartheid, is fully committed to the prohibition of racial discrimination in sport: the term "apartheid" means a system of legalized racial segregation and discrimination its systematic oppression, which is carried out in South Africa, and "apartheid in sport" means the implementation of the policy and practice of such a system in sports, both among professionals and amateurs (International Convention against Apartheid in Sport, 1985).

At the same time, Article 2 of the Racial Equality Directive defines discrimination as occurring where one person is treated less favorably than another is, has been or would be treated in a comparable situation on grounds of racial or ethnic origin (Council Directive 2000/43/EC, 2000). According to the Council of Europe's European Commission against Racism and Intolerance, racism is the belief that grounds such as "race", color, language, religion, nationality or national or ethnic origin justify contempt for a person or group of persons, or the notion of personal superiority. or groups of people (European Commission against Racism and Intolerance (ECRI), 2002).

The special attention is paid to General Policy Recommendation № 12 on Combating Racial Discrimination in Sport in 2009, which recommends: (a) Adopt and implement antidiscrimination legislation that provides for universal access to sport along with punishment for acts of racism; (b) to establish associations against racism in sport; (c) to train the police to detect and combat racism in sport; (d) to raise awareness of examples of racism and racial discrimination in sport (European Commission against Racism and Intolerance (ECRI), 2009).

Thus, within the broad framework of human rights, international instruments direct states and stakeholders to promote non-discrimination in sport and to recognize gender rights. They set minimum standards that encourage states to adopt and implement measures, including legislation, to eliminate discrimination based on gender (Patel, 2021).

Ukraine's experience in combating and combating discrimination in sport

For the Ukrainian legislator, the improvement of the legal framework for combating discrimination in sports, in particular in terms of responsibility for any manifestations of discriminatory actions against others, remains an urgent issue. The general rule on liability in connection with the violation of equality of citizens depending on their race, nationality, religious beliefs, disability, and other grounds is provided by criminal law and provides for liability in the form of fines or restraint of liberty for up to 5 years, deprivation of the right to hug certain positions or engage in certain activities for up to 3 years or without such (Law № 2341III, 2001). However, this article is called a "ghost article" because the latter is rarely used in practice. It seems that due to the vagueness of the disposition and the specifics of its application, it is not able to provide absolute protection for the equality of citizens. Sanctions in cases under this article are rarely applied by the courts, and, as a rule, the case either does not reach the court at all, or the qualification is changed to another article. If there are signs of other criminal offenses, the actions of the perpetrators are often classified under articles that provide a motive for prejudice (for example, as hooliganism) (Cvirkun, 2021).

In addition, according to the practice of criminal investigations into any manifestations of discrimination, over the past 5 years, 616 criminal proceedings have been opened for offenses committed on the grounds of intolerance, most of which (over 60\%) were closed due to lack of corpus delicti. Thus, on the one hand, every year the number of cases of law enforcement officers applying the article on violation of equality of citizens increases, on the other hand - statistics show the low efficiency of this article and the selective approach of investigators to qualify for it. At the same time, $4 \%$ of such cases have been sent to court, and $30 \%$ are still ongoing (Report on the results Research, 2021). At the same time, there is no official data on the number of open cases related to discrimination in sports, which is evidence of the imperfection of the mechanism of investigation and prosecution for discriminatory acts in sports. It is obvious that we can say that the victims have no motivation to complain about any manifestations of discrimination. Accordingly, there is an objective need to create 


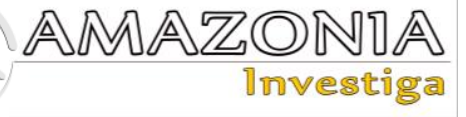

a mechanism that would effectively prevent and violate human rights violations in the field of sport.

The national legislator has repeatedly tried to resolve the situation with criminal prosecution for discrimination. Thus, the draft Law on Amendments to the Criminal Code of Ukraine (on Combating Hate Crimes on the Grounds of Sexual Orientation and Gender Identity) was registered in the Parliament. It complements the list of aggravating circumstances in the commission of certain crimes "on the grounds of intolerance of a person's sexual orientation or gender identity." However, there are three alternative versions of this bill. Two of them, apparently, are simply designed to avoid the expression "gender identity of a person" or at least reduce the number of mentions of gender in the Criminal Code of Ukraine (Cvirkun, 2021). However, none of the bills was adopted due to the lack of justification.

International experience in combating and combating discrimination in sport

In contrast to Ukraine, in other countries, along with criminal liability, there is also administrative liability. In Belgium, for example, the essence of administrative liability is reduced to the imposition of a fine or the imposition of a prohibition. The latter is a preventive measure of punishment, because it is derived from the opportunity to attend sports competitions for some time. According to T. Tymofeichyk, responsibility for combating racism in sport lies with both state institutions of power (legislature, courts, police, state bodies responsible for sport, local authorities) and non-governmental organizations (professional and amateur sports associations of the national level, clubs, local sports associations, fan clubs, player organizations, anti-racist associations, etc.) (Timofeychik, (2014). Therefore, a special body is often created and functions, the competence of which includes counteracting and combating discriminatory actions in the field of sports. For example, in Spain there is a State Commission for Combating Violence, Racism, Xenophobia and Intolerance in Sport, which is responsible for maintaining a register of fans and associations / groups of fans, as well as the right to propose liability for both fans and sports clubs or federations.

The Australian Government has incorporated into the national framework, in accordance with the Racial Discrimination Act 1975, the provisions of the International Convention on the
Elimination of All Forms of Racial Discrimination. At the same time, the Australian Commission on Human Rights and Equal Opportunities is responsible for investigating sport offenses and discrimination in the name of the country and has developed several awareness-raising initiatives in recent years to combat the harmful effects of racism in society, including sporting activities. The campaign, entitled Racism: It Stops with Me, is part of a national strategy to combat racism and promotes a clear understanding by the Australian community of what racism is and how to prevent and combat it.

In addition, in some countries there is an institute of ombudsman in the sports field. Here are some examples of them: 1) Sport Specific Ombudsmen - i.e., USA Fencing has an Ombudsman role which: will develop a panel with one person in each region to determine the issues that exist for the referee corps and work with the members of the FOC to develop solutions; 2) Sport Specific Ombudsmen - i.e., The United Kingdom's Independent Football Ombudsman: is appointed by the Football Association, the Football League and the Premier League, in consultation with the Department for Culture, Media and Sport. The IFO provides independent external scrutiny of complaints within a transparent, accountable and effective system of self-regulation by the football authorities; 3) Sport Integrity Ombudsman - i.e., The Austrian Fair Play Code Ombudsman is: a professional and confidential first point of contact for athletes and other stakeholders in sport who have information on past or planned match fixing activities. The Ombudsman office advises and offers guidance on how to handle suspicious and potentially dangerous situations best in relation to match fixing (Fowlie, 2017).

Slovenia is one of the few countries where the ombudsman's activity is regulated at the legal level in terms of protection of athletes' rights. The procedure for appealing to the ombudsman is confidential and informal. That is, the party to the dispute may seek advice or evaluate actions without involving other parties. The ombudsman does not disclose the results of the procedure to the public. In addition to confidentiality, a great advantage of the procedure for contacting the ombudsman in Slovenia is the right of athletes to contact him free of charge, and such access is provided for all athletes, local sports organizations, and sports federations (Kraljić, \& Drnovšek, 2021). 
In addition to the above, it is worth considering the proposals of foreign scientists to establish separate institutions for the protection of human rights in the field of sports at the international level. There is a proposition to establish International Anti-Discrimination in Sport Unit (IADSU), which would act as a watchdog and enforcement body to fight against discrimination in sport (Patel, 2015). In order to close the gaps, IADSU will have the power to investigate cases of discrimination, apply changes to the rules and impose fines on sports authorities for noncompliance with the code of conduct, such as restricting participation in major sporting events. Another important function of the IADSU would be to provide education and training to sports bodies and athletes on inclusion and exclusion, as well as on physical and non-physical human differences. Training can be offered to familiarize groups with the basic human rights provisions that exist to protect athletes (Patel, 2021).

Also, one of the recommendations was to create a sports ombudsman who would give athletes the voice and ensure the experience of combating discrimination against spectators of sports competitions deserves special attention. On the basis of Council Decision 2002/348/JHA, data exchange between national football information points has been developed. Services and/or sports authorities are now able to exchange operational information on high-risk supporters with police services and/or sports authorities. Furthermore, the Commission also promotes the wide use of the Handbook for Police Cooperation and supports pan-European anti-sports violence training for police officers and safety personnel (Katsarova, 2021).

\section{Conclusions}

Thus, one of the current problems in the field of sports is combating any manifestations of discrimination against both athletes and fans. Accordingly, there is an urgent need to create an effective mechanism for overcoming discrimination against the above category of people, which, in turn, will guarantee the protection of their rights as universal value.

Considering the experience of other countries, the priority for Ukraine should be the creation of the institution of sports ombudsman, given the ineffectiveness of pre-trial investigation and trial of causes related to violations of equality of citizens depending on their race, nationality, religion and other characteristics. In addition, the criminal legislation needs to be improved in terms of clarifying the disposition of Article 161 of the Criminal Code of Ukraine. It is also advisable to establish administrative liability for non-compliance with anti-discrimination legislation by amending the Code of Ukraine on Administrative Offenses, which, in turn, will facilitate more prompt prosecution for human rights violations in the field of sports.

\section{Bibliographic references}

Council Directive 2000/43/EC. (2000). Compendium of international and regional standards against racism, racial discrimination, xenophobia and related intolerance. - E/CN.4/2004/WG.21/5. 13 Jan. 2004, 376-385. Recovered from: https://digitallibrary.un.org/record/520839?1 $\mathrm{n}=\mathrm{ru}$

Cvirkun, N. (2021). Criminal-legal support of counteraction to criminal offenses on the basis of hatred. Bulletin of the Criminological Association of Ukraine, 1 (24), 60-67. Recovered from: http://dspace.univd.edu.ua/xmlui/bitstream/h andle/123456789/10412/Kryminalno_pravo ve_Tsvirkun_2021.pdf?sequence $=1 \&$ isAllo wed=y

Denison, E., Bevan, N. \& Jeanes, R. (2021). Reviewing evidence of LGBTQ+ discrimination and exclusion in sport. Sport Management Review, 24 (3), 389-409. DOI: 10.1016/j.smr.2020.09.003.

European Commission against Racism and Intolerance (ECRI) (2002). Ecri General Policy Recommendation no. 7 on national legislation to combat racism and racial discrimination. Recommendation of 13 December 2002. Recovered from: https://rm.coe.int/ecri-general-policyrecommendation-no-7-revised-on-nationallegislatio/16808b5aae.

European Commission against Racism and Intolerance (ECRI) (2009). Ecri General Policy Recommendation no 12: Main topics. Recommendation of 19 December 2008. Recovered from: https://bit.ly/2UYIuCO.

Fowlie, F. (2017). Prospects for a Sports Ombudsman in Canada. Laws, 6 (1), 5. DOI: 10.3390/laws6010005.

International Convention against Apartheid in Sport (1985). Convention of 10 December $1985 . \quad$ Recovered from: https://zakon.rada.gov.ua/laws/show/995_12 2\#Text.

Katsarova, I. (2021). Fighting discrimination in sport. European Parliamentary Research Service. Recovered from: https://www.europarl.europa.eu/RegData/etu 


\section{AMA更ONDA}

des/BRIE/2021/696163/EPRS_BRI(2021)69 6163_EN.pdf.

Kilvington, D., \& Price, J. (2018). Sport and Discrimination. London: Routledge.

Kraljić, S., \& Drnovšek, K. (2021). Ombudsman for Athletes' Rights - the example of Slovenia. Proceedings of the Faculty of Law in Split, 1(58), 151-161. DOI: 10.31141/zrpfs.2021.58.139.151.

Lapchick, R. (2020). Racism reported in sports decreasing but still prevalent. ESPN. Recovered from: https://www.espn.com/espn/story/_id/28738 336/racism-reported-sports-decreasingprevalent.

Law № 2341-III. Criminal Code of Ukraine. Information of the Verkhovna Rada of Ukraine, № 25-26, 2001. Recovered from https://zakon.rada.gov.ua/laws/show/234114

Malm, C., Jakobsson, J., \& Isaksson, A. (2019). Physical Activity and Sport - Real Health Benefits: A Review with Insight into the Public Health of Sweden. Sports, 7 (127). Recovered from: https://bit.ly/2UQYdnk.

Marivoet, S. (2014). Challenge of Sport Towards Social Inclusion and Awareness-Raising Against Any Discrimination. Physical culture and sport. studies and research, 63, 3-11. DOI: $10.2478 /$ pcssr-2014-0017.

Oliver, P., \& Lusted, J. (2015). Discrimination cases in grass-roots sport: comparing Australian and English experiences. Sport in Society, 18, 529-542. DOI: 10.1080/17430437.2014.976003.

Patel, S. (2015) Inclusion and Exclusion in Competitive Sport: sociolegal and regulatory perspectives. London: Routledge.

Patel, S. (2021). Gaps in the protection of athletes gender rights in sport - a regulatory riddle. The International Sports Law Journal. DOI: 10.1007/s40318-021-00182-2.

Phillips, J. (1997). Racial Discrimination in Sports: Unequal Opportunity for Equal Ability. Sociological Focus, 30 (4), 333-344. DOI: 10.1080/00380237.1997.10571084.

Report on the results Research (2021). The practice of investigating into Ukraine crimes committed on the grounds of intolerance.
Recovered from: https:/ulaf.org.ua/wpcontent/uploads/2021/06/\%D0\%97\%D0\%B 2\%D1\%96\%D1\%82-\%D0\%B7\%D0\%B0$\% \mathrm{D} 1 \% 80 \% \mathrm{D} 0 \% \mathrm{~B} 5 \% \mathrm{D} 0 \% \mathrm{~B} 7 \% \mathrm{D} 1 \% 83 \% \mathrm{D} 0$ $\%$ BB\%D1\%8C\%D1\%82\%D0\%B0\%D1\%82 $\% \mathrm{D} 0 \% \mathrm{~B} 0 \% \mathrm{D} 0 \% \mathrm{BC} \% \mathrm{D} 0 \% \mathrm{~B} 8$ $\% \mathrm{D} 0 \% \mathrm{~B} 4 \% \mathrm{D} 0 \% \mathrm{BE} \% \mathrm{D} 1 \% 81 \% \mathrm{D} 0 \% \mathrm{BB} \% \mathrm{D}$ 1\%96\%D0\%B4\%D0\%B6\%D0\%B5\%D0\%B D\%D0\%BD\%D1\%8F-1.pdf

Reznik, O., Muzychuk, O., Andriichenko, N., Yakushchenko, Y., \& Korzh, S. (2020). Fight Against Doping: Experience of Ukraine and European States. Amazonia Investiga, 9(27), 34-41.

https://doi.org/10.34069/AI/2020.27.03.4

Shevchenko, O. (2010). Discrimination problems in sports. K. Gusova, A. Solovyova, Sports law: development prospects. AllRussian public organization «Association of Russian Lawyers»: Moscow.

Teetzel, S., \& Weaving, C. (2017). Gender Discrimination in Sport in the 21st Century: A Commentary on Trans-Athlete Exclusion in Canada from a Sociohistorical Perspective. Sport History Review, 48, 185-193. DOI: 10.1123/shr.2017-0004.

Timofeychik, T. (2014). Discrimination in sports: the legal aspect. Current issues of international public and private international law, 6, 27-39. Recovered from: https://bit.ly/3t1zJ7r.

United Nations (2015) Final report of the Human Rights Council Advisory Committee on how sport and the Olympic ideals can be used to promote human rights for all and to strengthen their universal respect. Recovered from: https://undocs.org/ru/A/HRC/28/76.

United Nations (1948) Universal Declaration of Human Rights of December 10. Recovered from

https://www.un.org/en/udhrbook/pdf/udhr_b ooklet_en_web.pdf

Zenquis, M., \& Mwaniki, M. (2019). The Intersection of Race, Gender, and Nationality in Sport: Media Representation of the Ogwumike Sisters. Journal of Sport and Social Issues, 43 (1), 23-43. DOI: $10.1177 / 0193723518823338$. 